池 淵 純 子

多根記念眼科病院

\title{
Relationship between stereopsis and improvement of in the treatment of amblyopia
}

\author{
Junko Ikebuchi \\ Tane Memorial Eye Hospital
}

要 約

弱視治療の目的は、視力のみならず立体視を含む良好な両眼視機能の獲得である。

立体視の評価において、solid patternとrandom dotでは立体視の成績が異なるため、弱視の立体視 の検査はそれぞれの検查表の特徴を理解したうえで選択して行うことが重要である。よって今回 Titmus Stereo TestsとTNO Stereo Testを用いて弱視の立体視の評価を行った。

立体視検查の結果は、不同視弱視と屈折異常弱視では良好な立体視が得られたが、微小斜視弱視 では立体視は不良であった。不同視弱視の立体視獲得の過程で、Titmus Stereo Tests では $0.2 \sim 0.4$ の間で急激に立体視が向上し、TNO Stereo Testでは視力とともに立体視が向上する傾向を示す症例 が多くみられた。これは正常成人の片眼の視力を漸増遮閉膜にて低下させたときの立体視の低下と 似た傾向を示した。屈折異常弱視で治療開始時視力が両眼ほぼ等しい場合は、片眼のみ低視力の場 合に比べて低い視力でも立体視がみられ、両眼を漸増遮閉膜で視力低下させた正常成人のモデルと 似た傾向を示した。

アイパッチによる健眼遮閉を 8 時間以上行った不同視弱視では、遮閉開始年齢や遮閉期間による 違いで立体視検査の結果に差はみられなかった。

今回の結果では健眼遮閉の立体視に与える影響は大きくはなかったが、従来より遮閉治療につい てはいくつかの副作用が報告されており、弱視治療を行ううえでは十分なインフォームドコンセン トや定期的な経過観察が必要であると考える。

別冊請求先（５50-0024）大阪市西区境川 1 - 1 - 39

多根記念眼科病院 池 淵 純 子

Tel. $06-6581-5800$

Key words : amblyopia, stereopsis, solid pattern, random dot, occlusion therapy 


\section{Abstract}

Acquisition of stereopsis is as important as that of good visual acuity in the treatment of amblyopia. In the stereoscopic vision tests, understanding of characteristics of each stereoscopic chart is also important in the selection of stereoscopic charts, because the result of solid pattern stereogram is different from that of random dot stereogram. Based on these results, Titmus stereo test chart and TNO stereo test chart were used to estimate stereopsis in amblyopic patients.

Anisometropic and ametropic amblyopia patients had good stereopsis, although microtropic patients had poor stereopsis. In the process of acquisition of stereopsis in anisometropic amblyopia patients, stereoscopic vision was improved markedly when Titmus stereo test chart was used in patients who had vision of 0.2 , 0.3 and 0.4 . On the other hand, stereoscopic vision was improved in proportion to the improvement of visual acuity when TNO stereo test chart was used. These patterns of acquisition of stereoscopic vision resembled those of normal adult subjects when their visual acuities were decreased unilaterally by the use of stepwise occlusion filters. In the case of ametropic amblyopia patients whose visual acuities of both eyes were equal in the beginning of the treatment, stereopsis was better in patients with bilateral poor vision than in patients with unilateral low vision. These results resembled the case of maintenance of stereoscopic vision in normal adults whose visual acuity was decreased bilaterally by the use of stepwise occlusion filters. In the case of anisometropic patients who were treated by more than eight hours complete occlusion, the beginning age of occlusion and the duration of occlusion therapy had no effect on the results of stereoscopic vision tests.

Although occulusion therapy had little influence on stereoscopic vision, adverse effects of occlusion therapy have also been reported.

It was thus suggested that the well informed consent and the long-term and precise follow-up of the patients were essential in the treatment of amblyopia.

\section{I．緒言}

弱視治療の最終目標は、弱視眼の視力の向上 のみならず、立体視を含む良好な両眼視機能の 獲得にある。日本弱視斜視学会の弱視の治癒基 準の判定内容は、両眼視として60sec. of arc（以 下”と記す）の立体視をあげている ${ }^{1) 。 ま た 、 ~}$ 1998年に粟屋 ${ }^{2)}$ は弱視の治瘉基準の中で、より 正常に近い判定基準として立体視40”を提言し ていることからも、弱視治療を評価するうえで、 立体視は重要な要素の一つである。

立体視の評価については、すでにわれわれは 正常人の片眼の視力を低下させて近見立体視に ついて再評価 ${ }^{3)}$ を行った。その結果、分離方法 にかかわらずsolid patternがrandom dotより立 体視が良好であった。このことは過去の報告 ${ }^{4)}$ －9）とも一致し、この点を考慮し、今回立体視 の評価には、solid patternのTitmus Stereo Testsと random dotのTNO Stereo Testを行い、 弱視治療における視力の向上と立体視の関係に ついて検討したので報告する。

\section{II . 対象と方法}

対象は、昭和63年11月より平成 9 年 9 月まで に当院および楠部眼科にて、完全矯正眼鏡装用 および健眼遮閉にて治療を行った斜視のない遠 視性不同視弱視 41例、経線弱視を含む屈折異常 弱視32例、不同視のある微小斜視弱視10例であ る。屈折検査は、 $1 \%$ 塩酸シクロペントレート または $1 \%$ 硫酸アトロピンを点眼して行った。 近見立体視検査にはTitmus Stereo TestsとTNO Stereo Testを使用し、弱視眼の視力と近見立体 視の結果および立体視の獲得過程について検討 した。また、不同視弱視については健眼遮閉と 立体視の関係についても検討した。

\section{III. 結 果}

\section{1. 不同視弱視}

不同視弱視 41 例の治療開始年齢は 3 歳 10 ケ月 から 11 歳 9 ヶ月、平均 6 歳 2 ヶ 月で、治療開始

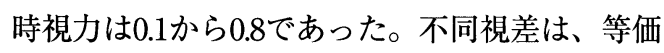
球面法にて $\mathrm{S}+2.0 \mathrm{D}$ から $\mathrm{S}+6.4 \mathrm{D}$ で、平均 $\mathrm{S}+3.5 \mathrm{D}$ であった。弱視治療は完全矯正眼鏡を装用し、 
遮閉療法はアイパッチ、遮閉膜、1\%硫酸アト ロピンを使用した。41例中38例に健眼遮閉を行 い、 3 例が眼鏡装用のみであった。治療後1.0以 上に視力が向上したものは41例中 36 例 $(87.8 \%)$ であった。

治療開始時、治療後、最終来院時のTitmus Stereo TestsとTNO Stereo Testによる立体視の 推移を図1a,bに示す。

Titmus Stereo Testsでは、治療開始時の立体 視は（一）から80"、治療後の立体視は400" から $40 "$ 、最終来院時には $200 "$ から $40 "$ であっ た。最終来院時に $100 ”$ より良好な立体視が獲得 できたのは、測定可能であった 34 例中 24 例 (70.6\%) であった。

TNO Stereo Testでは、治療開始時の立体視 は（-）から120"、治療後の立体視は1980" から 60"、最終来院時の立体視は1980" から 30 ”であった。最終来院時に $120 "$ より良好な立 体視が獲得できたのは、41例中29例（70.7\%） であった。

Titmus Stereo TestsとTNO Stereo Testの いずれにおいても治療開始時より治療後に立体 視が向上し、また最終来院時にさらに向上して

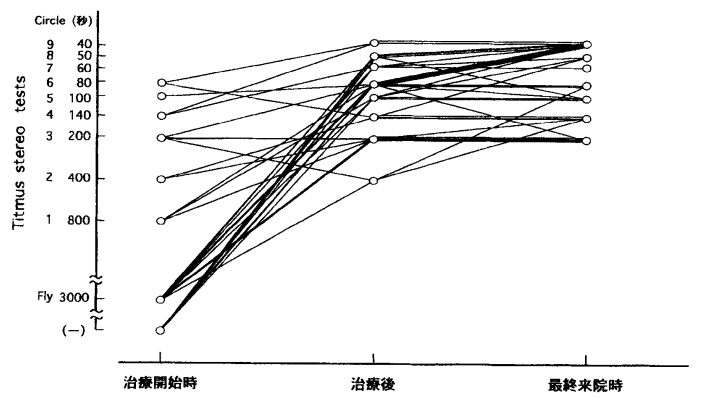

図 1 a. Titmus stereo testsの推移（不同視弱視）

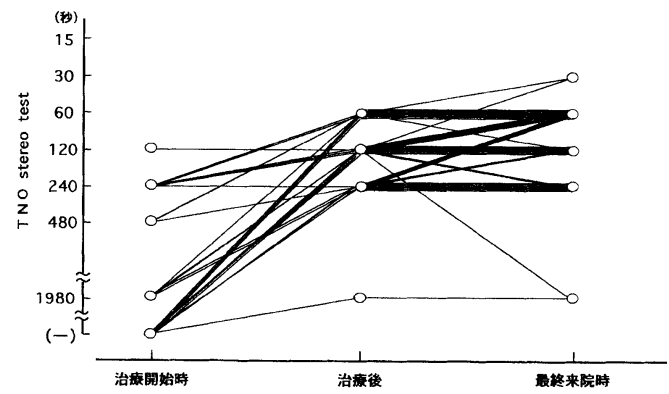

図 1 b. TNO stereo testの推移（不同視弱視）
いく傾向を認めた。

弱視治療中の視力の変化とTitmus Stereo Testsの立体視の向上について具体症例を示す (図 2 )。症例K.N.は 4 歳 9 ヶ月の不同視弱視の 男児で、完全矯正眼鏡装用とアイパッチで治療

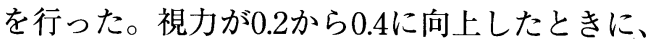
立体視が（-）から200”に急激に向上し、そ の後も視力の向上とともに立体視もさらに向上 していく傾向があった。こうした傾向が、 Titmus Stereo Testsでは特徴的にみられた。

次に弱視治療中の視力の変化と TNO Stereo Testの立体視の向上について具体症例を示す (図 3 )。症例T.M. は 3 歳10ヶ月の不同視弱視の 男児で、完全矯正眼鏡装用とアイパッチで治療 を行った。弱視眼の視力の向上とともに、立体 視は（-）より60” に徐々に向上した。こうし た傾向が、TNO Stereo Testでは特徴的にみら れた。

また、遮閉治療、特にアイパッチによる健眼 遮閉が立体視に及ほす影響を知るために、健眼 遮閉の期間と立体視の関係および治療開始年齢 と立体視の関係について検討した。対象は、1 日 8 時間以上のアイパッチによる健眼遮閉を行

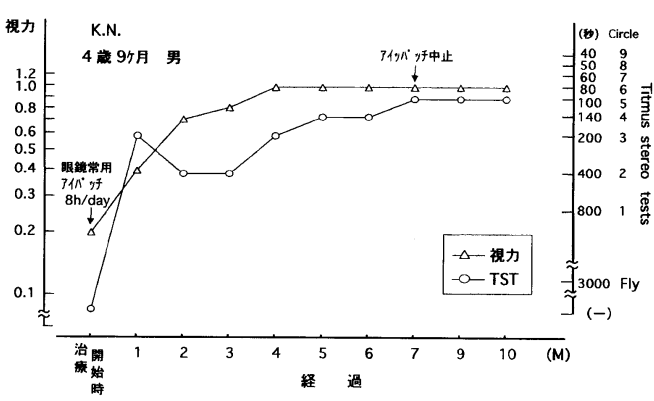

図 2. 視力の変化とTitmus stereo testsの推移

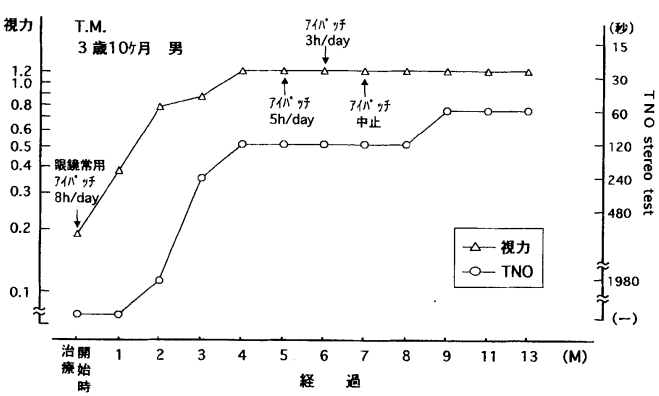

図 3. 視力の変化と TNO stereo testの推移 
った不同視弱視34例で、治療開始年齢は 3 歳 10 ヶ月から10歳10ケ月、平均 5 歳10ケ月であった。 8 時間の遮閉を継続して行った遮閉期間は 2 ヶ 月から 22 ケ月で平均 6.2 ケ、 8 時間未満の遮閉 期間を加えると、 2 ケ月から 31 ケで平均 10.6 ケ月であった。

治療開始年齢および遮閉期間と立体視の結果 を示す（表 1 、表 2 )。

治療開始年齢と立体視の関係および健眼遮閉 の期間と立体視の関係では、表 1 、表 2 に示す ように、Titmus Stereo TestsとTNO Stereo Testのいずれにおいても、良好な立体視の獲得 率にあきらかな差はみられなかった。

表 1．治療開始年齢と立体視

\begin{tabular}{|c|c|c|c|}
\hline & $\begin{array}{l}\text { Titmus stereo tests } \\
100^{\prime \prime} \text { より良好 }\end{array}$ & $\begin{array}{l}\text { TNO stereo test } \\
\text { 120" より良好 }\end{array}$ \\
\hline \multirow{2}{*}{$\begin{array}{l}\text { 治 } \\
\text { 療 } \\
\text { 開 } \\
\text { 始 } \\
\text { 年 } \\
\text { 䟠 }\end{array}$} & 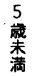 & $\begin{array}{c}6 / 9 \\
(66.7)\end{array}$ & $\begin{array}{r}7 / 10 \\
(70.0)\end{array}$ \\
\hline & $\begin{array}{l}5 \\
\text { 警 } \\
\text { 上 }\end{array}$ & $\begin{array}{c}16 / 21 \\
(76.2)\end{array}$ & $\begin{array}{l}17 / 24 \\
(70.8)\end{array}$ \\
\hline \multicolumn{2}{|c|}{ 計 } & $\begin{array}{l}22 / 30 \\
(73.3)\end{array}$ & $\begin{array}{l}24 / 34 \\
(70.6)\end{array}$ \\
\hline
\end{tabular}

表 2 。遮閉期間と立体視

\begin{tabular}{|c|c|c|c|}
\hline & $\begin{array}{l}\text { Titmus stereo tests } \\
100^{\prime \prime} \text { より良好 }\end{array}$ & $\begin{array}{l}\text { TNO stereo test } \\
\text { 120" より良好 }\end{array}$ \\
\hline \multirow{3}{*}{$\begin{array}{l}\text { 遮 } \\
\text { 閉 } \\
\text { 期 } \\
\text { 間 }\end{array}$} & $\begin{array}{l}\underset{\mathrm{M}}{\mathrm{M}} \\
\text { 以 } \\
\mathrm{F}\end{array}$ & $\begin{array}{l}14 / 17 \\
(82.4)\end{array}$ & $\begin{array}{l}15 / 21 \\
(71.4)\end{array}$ \\
\hline & $\begin{array}{l}7 \\
12 \\
12 \\
M\end{array}$ & $\begin{array}{l}6 / 10 \\
(60.0)\end{array}$ & $\begin{array}{r}6 / 10 \\
(60.0)\end{array}$ \\
\hline & $\begin{array}{l}13 \\
M \\
\text { 以 } \\
\text { 上 }\end{array}$ & $\begin{array}{l}2 / 3 \\
(66.7)\end{array}$ & $\begin{array}{c}3 / 3 \\
(100.0)\end{array}$ \\
\hline \multicolumn{2}{|c|}{ 計 } & $\begin{array}{l}22 / 30 \\
(73.3)\end{array}$ & $\begin{array}{l}24 / 34 \\
(70.6)\end{array}$ \\
\hline
\end{tabular}

( ) $\%$

\section{2. 屈折異常弱視}

屈折異常弱視32例の治療開始年歯令は 3 歳から 8 歳10ケ月、平均 5 歳 7 ケ月で、治療開始時視

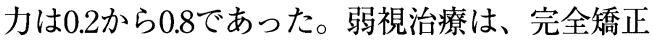
眼鏡を装用し、片眼のみ視力が向上し左右差が 生じた場合のみ、アイパッチと遮閉膜で遮閉療 法を行った。32例中12例が健眼遮閉を行い、20
例は眼鏡装用のみであった。治療後1.0以上に視 力が向上したものは、32例中 28 例 $(87.5 \%)$ で あった。

治療開始時、治療後、最終来院時のTitmus Stereo TestsとTNO Stereo Testによる立体視の 推移を図 4 a,bに示す。

Titmus Stereo Testsでは、治療開始時の立体 視は3000" から100" 、治療後の立体視は3000" から $40 "$ 、最終来院時には $200 ”$ から $40 "$ であっ た。最終来院時に $100 "$ より良好な立体視が獲得 できたのは、測定可能であった 24 例中 20 例 (83.3\%) であった。

TNO Stereo Testでは、治療開始時の立体視 は（一）から $120 "$ 、治療後の立体視は $240 "$ か ら60"、最終来院時の立体視は $480 "$ から $30 "$ で あった。最終来院時に120" より良好な立体視が 獲得できたのは、30例中 25 例 $(83.3 \%)$ であっ た。

屈折異常弱視においてもTitmus Stereo Tests とTNO Stereo Testによる立体視は治療開始時 より治療後に向上し、また、最終来院時にさら に向上していく傾向を認めた。

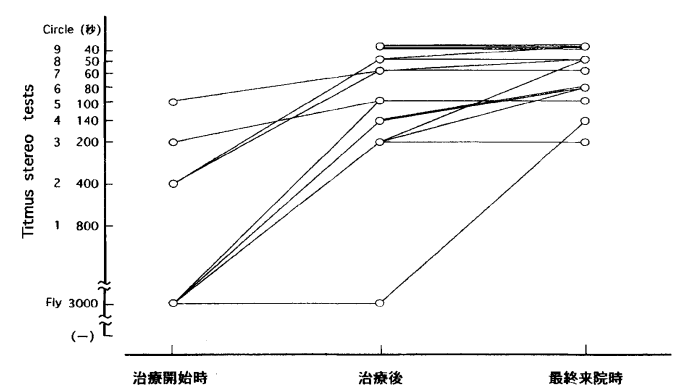

図 $4 \mathrm{a}$. Titmus stereo tests $の$ 推移（屈折異常弱視）

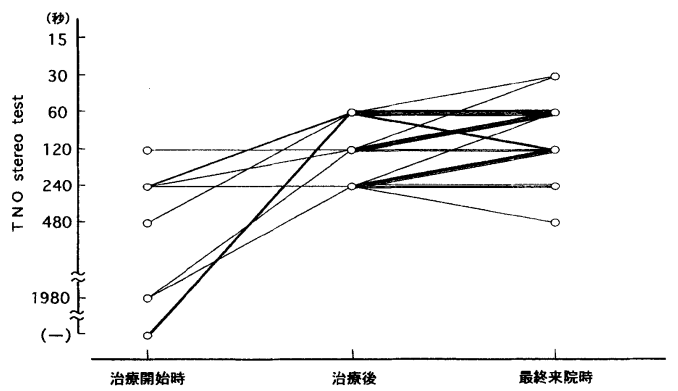

図 4 b. TNO stereo testの推移（屈折異常弱視） 
次に、屈折異常弱視16名の治療開始時での視 力と立体視を図 $5 \mathrm{a}, \mathrm{b}$ に示す。

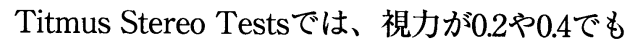
140”から200”の立体視を認め、またTNO

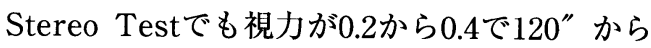
$240 ”$ の立体視を認めるものもあり、両眼に視力 差のないものは視力差のあるものに比べて、低 視力でも立体視が認められた。

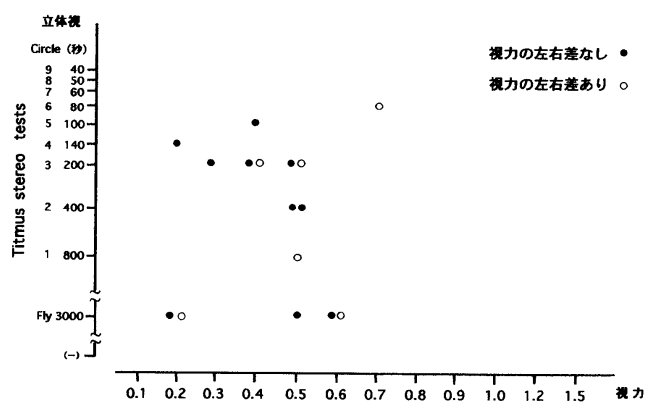

図 $5 \mathrm{a}$. 治療前の視力とTitmus stereo tests（屈折 異常弱視)

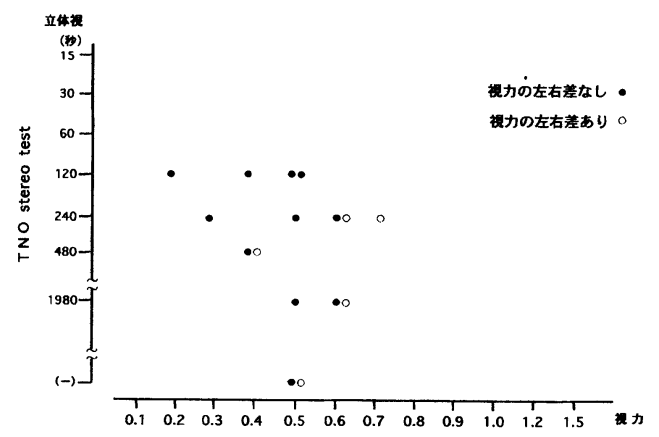

図 $5 \mathrm{~b}$. 治療前の視力とTNO stereo test（屈折異常 弱視)

\section{3 . 微小斜視弱視}

微小斜視弱視10例の治療開始年齢は 4 歳 3 ヶ 月から 9 歳10ヶ月、平均 6 歳10ヶ月で、治療開

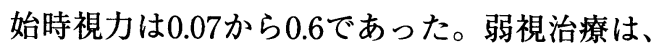
完全矯正眼鏡を装用し、遮閉療法は、アイパッ チと $1 \%$ 硫酸アトロピンを使用した。10例中 9 例に健眼遮閉を行い、 1 例は眼鏡装用のみであ った。治療後の視力は 0.3 から 1.0 までばらつきを 認め、1.0以上に視力が向上したものは 10 例中 2 例のみであり、不同視弱視や屈折異常弱視に比 べて少なかった。
治療開始時、治療後、最終来院時のTitmus Stereo TestsとTNO Stereo Testによる立体視の 推移を図 6 a,bに示す。

Titmus Stereo Testsでは、治療開始時の立体 視は（一）から400”、治療後および最終来院 時の立体視は（一）から200"であった。全例 $100 ”$ より良好な立体視を認めなかったが、10例 中 6 例に立体視が認められた。

TNO Stereo Testでは、治療開始時の立体視 は全例 $(-) 、$ 治療後および最終来院時の立体 視は（一）から1980"であった。全例120”よ り良好な立体視を認めなかったが、 9 例中 4 例 に立体視が認められた。

Titmus Stereo TestsとTNO Stereo Testの いずれでも治療開始時より立体視が向上した症 例は10例中 4 例に認めたが、良好な立体視が得 られた症例は認められなかった。

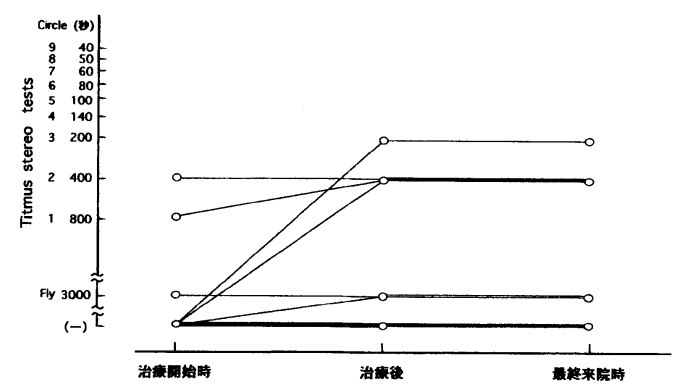

図 6 a. Titmus stereo testsの推移（微小斜視弱視）

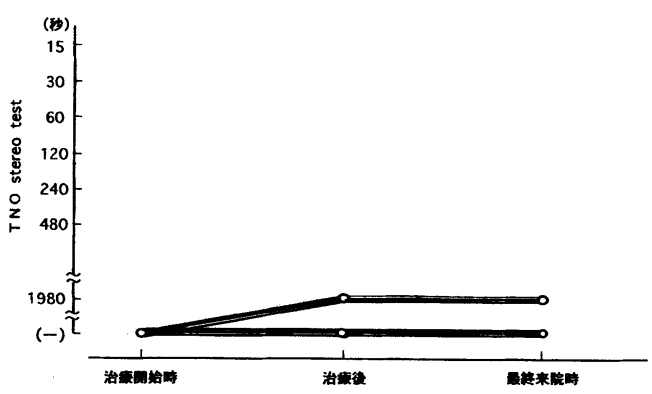

図 $6 \mathrm{~b}$. TNO stereo testの推移（微小斜視弱視）

\section{IV. 考按}

弱視は、視力の低下のみならず、様々な視機 能異常が関連した症候群である。それゆえに弱 視治療の評価は、弱視眼の視力の向上だけでは 
なく、立体視や読み分け困難、調節力、固視点、 輻湊や融像幅など視機能の総合的な評価が必要 である。

立体視の評価においては、solid patternと random dotでは結果に差異がみられるといわれ ている。Julesz ${ }^{10)}$ は立体視の成立過程において、 solid pattern stereogramでは左右の単眼視野に 投影された像をそれぞれパターン認識してから 融像、奥行き知覚を得ているが、random dot stereogramでは、左右の単眼視野にはパターン のない像が投影され、それを融像、奥行き知覚 を得るとともにパターン認識をしているとのべ ている（図 7 )。このように、成立過程が異な る可能性をはじめとして solid patternとrandom dotはさまざまな性質の違いを持っていると考え られる。

不同視弱視では、最終来院時にTitmus Stereo Testsにて100” より良好な立体視が70.6\%に、 TNO Stereo Testにて $120 "$ より良好な立体視 が70.7\%に獲得できた。島崎ら ${ }^{11)}$ はTitmus Stereo Testsでの結果として、不同視弱視の治 療前は立体視は低いが、治療により視力が向上 するとそれに対応して立体視も向上するとし、 今回もこれと一致した結果となった。また、不 同視弱視の具体症例の経過では、Titmus Stereo Testsでは視力 0.2 から 0.4 の間で急激に立体視が 向上し、その後さらに視力の向上とともに立体 視が向上していく傾向がみられた。TNO Stereo Testでは視力の向上とともに徐々に立体視が向

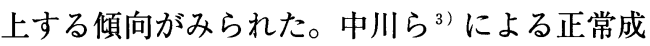
人の片眼を漸増遮閉膜にて視力低下させた時の Titmus Stereo Testsでの立体視の実験結果で は、 0.2 と0.3の間で立体視が急激に低下し、また

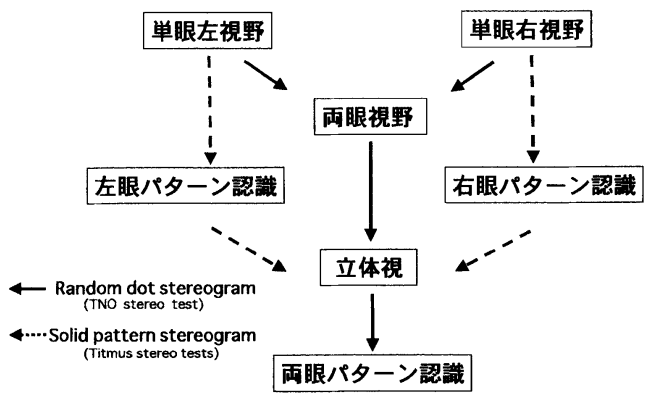

図 7 . 立体視の成立過程 （Julesz, 1971）
TNO Stereo Testでの同様の実験結果では立体 視は視力の低下とともに徐々に低下した。今回 の不同視弱視の立体視の獲得過程もこれと似た 傾向があった。

健眼遮閉と立体視の関係では、遮閉開始年齢 および遮閉期間について良好な立体視の獲得率 にあきらかな差はみられなかった。Birchら ${ }^{12)} の$ PLを用いた両眼視機能の発達に関する研究で は、融像は生後11.7週、立体視は生後12.3週に芽 生えるとし、粟屋 ${ }^{2)}$ もまた、立体視は生後 3 ケ 月から 4 ケ月で芽生え、 3 歳の終わりごろに 100” より良好なレべルに達するとしている。立 体視の発達過程を考慮すると、遮閉開始年齢は 4 歳未満と 4 歳以上を比較するのが妥当である が、対象の平均年齢が高く 4 歳未満が 1 人であ ったため、今回 5 歳未満と 5 歳以上で比較を行 ったが、そのかぎりではあきらかな差はみられ ず、遮閉開始年齢は立体視に影響を与えない結 果となった。また、遮閉期間の長さによっても 差がでない結果となった。これは、立体視の基 本的な部分がかなり早期に完成しているためと 考えられる。一方、不同視弱視の視力の感受性 は12歳ごろまでとされるが、粟屋 ${ }^{13)}$ は立体視の critical periodも視力と同様で、微弱な程度では あるが何らかの感受性は成人になっても長く続 くのではないかとのべている。また、 Nigel ${ }^{14)}$ の 最近の報告でも、立体視のcritical period につ いてはあきらかにされていない。今回、遮閉開 始年齢および遮閉期間は、立体視に影響を与え ない結果となった。しかし、このように感受性 期間が長く続くことから考えて、両眼視機能を こわさないよう留意して遮閉を行う必要がある と考えられる。

屈折異常弱視では、最終来院時にTitmus Stereo Testsで100”より良好な立体視が $83.3 \%$ に、またTNO Stereo Testでも120" より良好 な立体視が $83.3 \%$ に得られ、深井らの報告 ${ }^{15)}$ と ほぼ一致した結果となった。Simons ${ }^{16)}$ は、単眼 の視力低下が両眼の視力低下より立体視に与え る影響が大きいとし、低視力でも左右差が少な い方が立体視が良好であるとしている。中川ら 3)による漸増遮閉膜にて正常成人の視力を両眼 ともに低下させたときのTitmus Stereo Testsと 
TNO Stereo Testでの立体視可能な最終視力は、 Titmus Stereo Testsでは0.06で、TNO Stereo Testでは0.08で立体視が可能なものがあり、屈 折異常弱視の治療開始時で両眼がほぼ等しい低 視力の場合と似た傾向があった。今回、屈折異 常弱視の治療開始時における視力が 0.2 から 0.4 の 低視力であっても、Titmus Stereo Testsでは 140" から200"、TNO Stereo Testでも120" から240" の立体視を認め、屈折異常弱視では両 眼の視力差がなく、抑制がかかりにくいことを 反映していると考えられる。

微小斜視弱視は幅のある融像域とおおまかな 立体視を有するとされているが、今回最終来院 時にTitmus Stereo Testsで立体視が認められた のは60.0\%で、TNO Stereo Testでは1980" の 立体視が $44.4 \% に$ 認められたのみで、特にTNO Stereo Testでの立体視は不良であった。Robert $ら^{17)}$ は28例の微小斜視弱視に 5 種類の立体視検 査を行った結果、28例中 9 例ではいずれの検査 表でも立体視は（-）であり、Titmus Stereo Testsでは19例に800" から200”、TNO Stereo Testでは4例にのみ480" から240” の立体視を 認めたと報告している。富山ら ${ }^{18)}$ は弱視症例に 対して、遮閉治療経過中に視力の向上が停滞し た時、TNO Stereo Testによる立体視の有無に より視力の予後を判定している。微小斜視弱視 の症例ではTNO Stereo Testの立体視は不良で あるという今回の結果からも、TNO Stereo Testで立体視が不良である症例には微小斜視が 存在する可能性は高いといえる。弱視治療を行 う上で、TNO Stereo Testでの立体視検査は予 後の良否を判断するのに有用であると考えられ、 立体視検査にTNO Stereo Testを用いる重要性 を再認識した。

\section{V. 結 語}

弱視治療の目的は、視力のみならず立体視を 含む良好な両眼視機能の獲得である。今回、 Titmus Stereo TestsおよびTNO Stereo Test を用いて弱視の立体視を検討した結果、不同視 弱視と屈折異常弱視では良好な立体視が得られ たが、微小斜視弱視では立体視は不良であった。
それぞれ、Titmus Stereo TestsとTNO Stereo Testの結果は異なった。さらに不同視弱視で は、Titmus Stereo TestsとTNO Stereo Test での立体視の獲得過程に差がみられた。また、 健眼遮閉の立体視に与える影響は大きくはない が、弱視治療を行う上では従来よりいわれてい る心理的外傷等を考慮し、十分なインフォーム ドコンセントや定期的な経過観察が必要である。

（稿を終えるにあたり、御指導頂きました楠部 眼科楠部亨先生、御校閲頂きました近畿大学大 鳥利文教授に深謝いたします)

\section{文 献}

1）植村 恭夫：弱視に関する研究. 日眼 64 ： $663-738,1964$.

2 ）粟屋 忍: 弱視の治癒基準. 丸尾 敏夫, 他 （編）：眼科診療プラクティス 35 弱視診療の 実際，44-45，文光堂，東京，1998.

3 ）中川 絵里加, 他：漸増遮閉膜にて低下した 近見視力と近見立体視の関係について. 日本 視能訓練士協会誌投稿中.

4 ）小林 祐子, 他：立体視の判定における Titmus Stereo TestとRandom Dot E Testの 成績比較. 日本視能訓練士協会誌 6 （2）: 14-16, 1977.

5 ）福山 千代美, 他：両眼視力差によるTitmus Stereo TestとTNO Stereo Test立体視差度に ついて. 日本視能訓練士協会誌 7 （1）: 30-31, 1978.

6 ）田野上 恭子, 他 : Randot ${ }^{\circledR}$ ( Preschool Stereoacuity Test Chartの臨床評価. 日本視 能訓練士協会誌 $26: 187-193,1998$.

7 ) 湖崎 克, 他 : 各種近見立体視テストの比較 検討. 眼臨75：420-424, 1981.

8 ）和田 尚恵, 他：近見立体視の検討 - Lang, KATとT.S.T.の比較一。棟視能訓練士協会 誌13:25-28, 1985.

9 ）粟屋 忍, 他：“New Stereo Tests”による 立体視の検討. 眼紀 $32 ： 1270-1280,1981$.

10) Julesz B: Foundations of cyclopian Perception, 94-102, The University of Chicago 
Press, Chicago, 1971.

11）島崎 路子, 他：不同視性弱視と立体視. 日 本視能訓練士協会誌 7 （1）：32-35，1978.

12) Birch E E, et al. : Preferential looking assesment of fusion and stereopsis in infants aged $1 \sim 6$ months. Invest. Ophthalmol. Vis. Sci. $26: 366-370,1985$.

13）粟屋 忍：乳幼児の立体視の発達とその検查 法. 眼紀40：1-8，1989.

14) Nigel $W D:$ Critical periods and amblyopia. Arch. Ophthalmol. 116 : 502-505, 1998.
15）深井小久子：屈折異常弱視の病態と電気生理 学的特徵. 眼科 $37: 1035-1043,1995$.

16) Simons $K:$ Stereoacuity norms in young children. Arch. Ophthalmol. $99: 439-445$, 1981.

17) Robert P R, et al. : Stereopsis in small - angle strabismus. Am. J. Optom. Physiol. Optics. 61 : 491-498, 1984.

18）富山 園子, 他：弱視治療で視力の向上が停 滞したときに視力予後を左右する因子につい て. 眼臨91：1110-1112，1997. 